\title{
THE HUMAN BONE OXYGEN ISOTOPE RATIO CHANGES WITH AGING
}

\author{
BEATA STEPAŃCZAK ${ }^{1}$, KRZYSZTOF SZOSTEK ${ }^{1}$ and JACEK PAWLYTA ${ }^{2}$ \\ ${ }^{1}$ Department of Anthropology, Institute of Zoology, Jagiellonian University, Gronostajowa 9, 30-387 Cracow, Poland \\ ${ }^{2}$ GADAM Centre of Excellence, Institute of Physics, Silesian University of Technology, Krzywoustego 2, 44-100, Gliwice, Poland
}

Received 5 August 2013

Accepted 18 November 2013

\begin{abstract}
The oxygen isotope ratio $\left(\delta^{18} \mathrm{O}\right)$ in tissues is the outcome of both climatic and geographical factors in a given individual's place of abode, as well as the physiology and metabolism of his organism. During an individual's life, various rates and intensities of physiological and metabolic processes are observable in the organism, also within the bone tissue.

The aim of this study is to verify whether involutional changes occurring as a result of the organism's ageing have a significant impact on $\delta^{18} \mathrm{O}$ determined in the bone tissue.

The material used for analysis was fragments of the long bones taken from 65 people, (11 children and 54 adults), whose remains had been uncovered at the early mediaeval (X-XI century) cemetery located at the Main Market Square in Kraków (Poland).

The correlation analysis between $\delta^{18} \mathrm{O}$ of bone tissue and an individual's age shows that up to 40 years of age, such a relationship does not exist in both, males and females. However, the conducted correlation analysis prompted the observation that after 40 years of life, $\delta^{18} \mathrm{O}$ in bone tissue significantly drops as females increase in age.

Results suggest that the $\delta^{18} \mathrm{O}$ in bone tissue among older people may be the outcome not only of environmental factors but also involutional changes in bone linked to an organism's ageing. Therefore, the interpretation of $\delta^{18} \mathrm{O}$ results relating to the description of the origin and migrations of older individuals should be treated with caution.
\end{abstract}

Keywords: oxygen isotopes, phosphate, human remains, aging.

\section{INTRODUCTION}

The introduction of biochemical methods for the analysis of human remains has been very important for the development of research focused on establishing the place of origin and migration patterns within human groups diversified in terms of both time and space. An important place in this field is occupied by the analysis of stable isotopes of oxygen $\left(\delta^{18} \mathrm{O}\right)$ in human remains.
The proportion of stable oxygen isotopes $\left({ }^{18} \mathrm{O} /{ }^{16} \mathrm{O}\right)$ is expressed in the form of a relative measurement (using "delta" notation), where the oxygen isotope ratio of the investigated sample is related to the oxygen isotope composition of a standard and expresses in per mil (Benson et al., 2006), according to the formula:

$$
\delta^{18} \mathrm{O}(\%)=\frac{{ }^{18} \mathrm{O} /{ }^{16} \mathrm{O}_{\text {sample }}-{ }^{18} \mathrm{O} /{ }^{16} \mathrm{O}_{\text {standard }}}{{ }^{18} \mathrm{O} /{ }^{16} \mathrm{O}_{\text {standard }}} \times 1000
$$


The existence of a relationship between the $\delta^{18} \mathrm{O}$ ratio of the skeletal phosphate and the isotopic composition of the environment in which a given individual dwells has been confirmed by Longinelli (1984). By combining this fact with observations confirming a link between the isotopic composition of the oxygen in meteoric water with geographical and climatic conditions occurring in the area in question, it is possible to reconstruct the living area (or habitat) of both individuals and whole human groups (Dupras and Schwarcz, 2001; Hoogewerff et al., 2001; Kendall et al., 2013; Oelze et al., 2012; Szostek 2009; White et al., 2004a, 2004b; Włodarczak et al., 2011). As a result, research of this type conducted on skeletal material has become extremely useful for tracking the seasonal wanderings of both animals and people (Britton et al., 2009; Henton et al., 2010; Rubenstein and Hobson, 2004; Shaw et al., 2010) and also the migration of individuals between groups and the origin of settlement(s) in diverse areas (Knudson and Price, 2007; Leach et al., 2009; Prowse et al., 2007; Szostek et al., 2013; White et al., 1998).

Living organisms absorb elements from the resources available in their surrounding environment including the air, soil, water and food). This fact leads to the establishment of an elemental and isotopic equilibrium between plants, animals and people and the environment in which they live, which is reflected in the isotopic composition of their tissue (Kohn and Cerling, 2002; West et al., 2006).

Isotopes of an element differ in weight but not in gross chemical properties. However, according to the principles of quantum mechanics, the variable amount of neutrons and resultant slight differences in the mass of atoms leads to subtle differences in the physical properties of isotopes - the so-called isotope effect (Sharp, 2007). Isotopes of an element have slightly different equilibrium constants for a particular chemical reaction because the value of the bond energy required to break the chemical bonds in molecules vary depending on their isotopic composition. Hence, slightly different amounts of reaction products are made from substrates containing different isotopes. (Daux et al., 2008; Luz and Kolodny, 1989). The direct outcome of this is isotopic fractionation, entailing a change in the abundance ratio of isotopes during a chemical reaction or physical process. Isotopic fractionation leads to the noticeable enrichment of one isotope in comparison with another (Sharp, 2007).

Body water comprises a pool of stable oxygen isotopes incorporated into the structure of all the tissues of living organisms, including bones and teeth (White et al., 2004b; Warinner and Tuross, 2010; Wolf et al., 2011). In skeletal tissue, oxygen incorporated into the inorganic matter, mainly occurs in the form of phosphate, carbonate and hydroxide ions (Kohn and Cerling, 2002). It has been proved that in warm-blooded animals, oxygen isotope composition in the skeleton correlates with the $\delta^{18} \mathrm{O}$ ratio in the body water, but their final concentration results from diverse biological, behavioral and environmental factors (Kirsanow and Tuross, 2011; Kohn, 1996). During the process whereby oxygen is incorporated into the bone tissue, isotopic fractionation occurs, manifesting itself in the fact that the lighter ${ }^{16} \mathrm{O}$ isotope is taken up at a greater concentration than its heavier variant $\left({ }^{18} \mathrm{O}\right)$. This variation reflects the value of the fractionation coefficient $(\alpha)$, which in humans is maintained at a level of around 1.0214 (Longinelli, 1984).

The $\delta^{18} \mathrm{O}$ level of body water in warm-blooded animals is determined by the balance between assimilated and excreted oxygen (Bryant and Foerlich, 1995). In humans, the main source of oxygen in body water is drinking water, which comprises around $70 \%$ of the complete oxygen pool in an organism (Daux et al., 2008). The remaining portion of oxygen is supplied to the body from water contained in food, water originating from metabolic processes of food and atmospheric air. Oxygen loss in an organism occurs mainly through urination, sweating, and exhaling air (Luz and Kolodny, 1989; Widory 2004). Given that (oxygen in) drinking water makes up a substantial proportion of the general oxygen pool in the human organism, it would appear to be the main factor accounting for isotopic variation of oxygen in both body water and bone and dental tissue (Daux et al., 2008; Lécuyer et al., 1996). For historical and prehistoric human populations, the main source of drinking water was meteoric water, i.e. streams, rivers, lakes or wells occurring on the area permanently or temporarily settled by a given group (Dupras and Schwarcz, 2001; White et al., 2004b). The isotopic composition of meteoric water depends on geographic and climatic factors in a given area. The most important of these are latitude, altitude and distance inland as well as temperature, seasonal and amount effects (Bowen and Wilkinson, 2002; Fricke and O’Neil, 1999; Gat, 1996). A number of studies have revealed the existence of a positive relationship between both the oxygen isotope composition of the body water and drinking water, and between that of the drinking water and the phosphate groups building bone apatite, although slight differences are evident in the regression equation and the value of the correlation co-efficient between authors (Daux et al., 2008; Levinson et al., 1987; Luz and Koldny, 1989; Pollard et al., 2011). When the earlier discussed variation in the level of $\delta^{18} \mathrm{O}$ oxygen resulting from the environmental conditions in a given area is also taken into account, it can be concluded that the oxygen isotope ratios in bones and teeth reflect the oxygen isotope composition typical of the area where a given individual grew up and was living in adulthood (Longinelli, 1984; White et al., 2004a).

However, when analysing the regression line depicting the dependence between the $\delta^{18} \mathrm{O}$ level in the skeleton and the meteoric water, it is possible to observe that the $\delta^{18} \mathrm{O}$ ratio determined in the bone tissue is always higher than in the meteoric water. This is due to the fact that the values of the slope (a) and intercept (b) describing the 
regression line depend both on the percentage share of all the components containing oxygen atoms assimilated and excreted by the organism and also the values of the oxygen isotope fractionation accompanying metabolic changes in its body (Luz and Kolodny 1989). The results of experimental tests carried out on animals indicate that oxygen isotope variation in tissue may arise not only from environmental factors but also from interspecies and even individual variation in physiological processes connected with body size, an animal's metabolic rate and the type of thermoregulatory mechanism occurring in its case (Bryant and Froelich, 1995; Grimes et al., 2008; Wong et al., 1988). The final oxygen isotope concentration in animal tissue is also dependent on the kind of food that is available, including the quantity of water that is taken in and the manner in which it is assimilated and stored within the organism (Kohn, 1996). Research carried out by Zanconato et al. (1992) and Widory (2004) has shown that oxygen fractionation in the human organism decreases as a person's physical activity increases. The phenomenon occurs as a result of more intense oxygen diffusion through the lung capillaries during the breathing process, an increase in arterial tension and excessive water loss as a result of perspiration. Due to this, a statistically significant increase of oxygen isotope ratio is observed in healthy, more active individuals than in the organisms of less active individuals, the sick and also the elderly (Reitsema and Crews, 2011; Widory, 2004).

During an individual's life, various rates and intensities of physiological and metabolic processes are observable in the organism (Żołądź et al., 2011). Previous studies have shown that age-progressive disruptions of the balance between anabolic and catabolic processes, with a clear shift in the direction of the latter, are the essence of the ageing process (Lamberts et al., 1997). With age, the organism loses its ability to synthesize many functional and structural components. There is also a reduction in the activity level of vital processes and disruptions occur in water and mineral management. In response to the progressive destruction of cells and tissue, the body displays regressive changes, while failing to keep pace with the processes of renewal and regeneration (Arlot et al., 2005).

Significant changes also occur in the structure and functioning of bone tissue. First and foremost, there is a reduction in the regenerative properties of bone (Akkus et al., 2003; Bergot et al., 2009). Among older people, there is a reduction in the activity level of osteoblasts responsible for the creation of bone tissue, resulting in resorption processes gaining an advantage over those of bone creation. Moreover, disruptions appear in the calcium absorption process in the gastrointestinal tract. There is also an observable reduction in the synthesis of calcitonin, whose roles include the inhibition of osteoclast activity. These processes result in accelerated loss of bone mass, which can lead to osteoporosis (Stawińska et al., 2005; Steiger et al., 1992).
Another consequence of involutional processes in the skeleton is the change in the chemical structure of bone. Nyman et al. (2008) demonstrated a permanent agerelated reduction in the water content in bones, which is the consequence of the gradual general dehydration of the organism. The calcium and phosphorous content and $\mathrm{Ca} / \mathrm{P}$ ratio of human trabecular bone remain unchanged with normal ageing (Gałasińska and Gałasiński, 1959). The professional literature is not in agreement on changes in collagen content with age. Rogers et al. (1952) found increasing content of collagen in human bone with age, in contrast to the findings of other researchers who noted a fall with increasing age (Eastoe, 1956). Bone collagen, however, shows qualitative changes with age. Wang et al. (2002) indicated that an increase in stiffness of bone with ageing may be associated with increased enzymatic collagen cross-links.

Given the fact that the oxygen isotope level in tissues is the outcome of both climatic and geographical factors in a given individual's place of abode, as well as the physiology and metabolism of his organism, the question arises of whether involutional changes occurring as a result of the organism's ageing have a significant impact on the oxygen isotope composition determined in the bone tissue. If such oxygen isotope variation in bones were an outcome of age-related involutional processes, this could present a serious problem during the interpretation of the results of analyses relating to the description of the origin and migrations of older individuals.

The previous professional literature contains various attempts to describe this issue. For example, Kirsanow and Tuross (2011) studied the oxygen isotope ratios in rat tissue at consecutive stages of ontogenetic development. However, these studies focused on the link between oxygen isotope content in the organism and changes in body size during the animal's development rather than the age and ageing of the organism. These pilot studies therefore also aim to carry out research into whether the oxygen isotope composition in human bone tissue is dependent on an individual's age.

\section{SITE DESCRIPTION}

Kraków is located in southern Poland by the Vistula river, on the border between geographical regions with diverse landscapes, covering the outskirts of KrakowskoCzęstochowska Upland, Sandomierska Valley and Karpackie Foothills. Natural environmental reaches of the region provided favorable conditions for an extensive settlement supported with an excellent agricultural and material basis (Radwański, 1975). Like most of the earlymedieval cities, Kraków was established in conjunction with a castle (Wawel), initially forming a centre of tribal administration, and next - of state and church one (Rajman, 2004). Historical and archeological data confirm that already in the period between VII century and year 1257 Kraków was a dynamically developing settle- 
ment, in many aspects including social and economic side of life, with urban and state functions (so-called formative period of a city). Moreover, the city from that time was classified already as a leading trade centre, both locally and internationally (Rajman, 2004).

The cemetery was uncovered during archaeological work carried out at the Main Market Square in Kraków from 2005 to 2008 (Fig. 1). On the basis of a set of coins and ornaments found in the burial ground, its period of use has been dated to between the turn and end of the $11^{\text {th }}$ century. It is supposed that the cemetery came into being at the same time as the construction of St. Adalbert's Church, which took place in the $10^{\text {th }}$ century (although archaeologists do not exclude the possibility of it having functioned as a local cemetery unaffiliated to any church). The burial ground's period of functioning is closely linked to the need of a dynamically developing settlement and "economic zone" to occupy this area (Głowa, 2010; Kępa et al., 2011). So the cemetery was actually functioning before the official establishment of Kraków under Magdeburg Law in 1257.

Despite a great deal of archaeological work being undertaken, no early mediaeval pre-foundation cemetery has been recorded which would be appropriate for this settlement complex in terms of period of functioning and area of the occupied area. It is therefore assumed that the inhabitants of Kraków were buried in the discovered burial ground. Of course, there were some modest cemeteries in the area covered by the settlement of Kraków, which were situated by such churches as St Andrew's, St Martin's or St Giles', but they were not large enough to enable the population of Kraków to be laid to rest (Głowa, 2010).

Excavations have led to the discovery of 177 graves. The skeletons of 211 individuals were found in burial pits, while the remains of 47 people were found outside graves (in most cases individual bones or skeletal fragments). Within the cemetery, in which people of both sexes covering a full cross section of ages were buried,

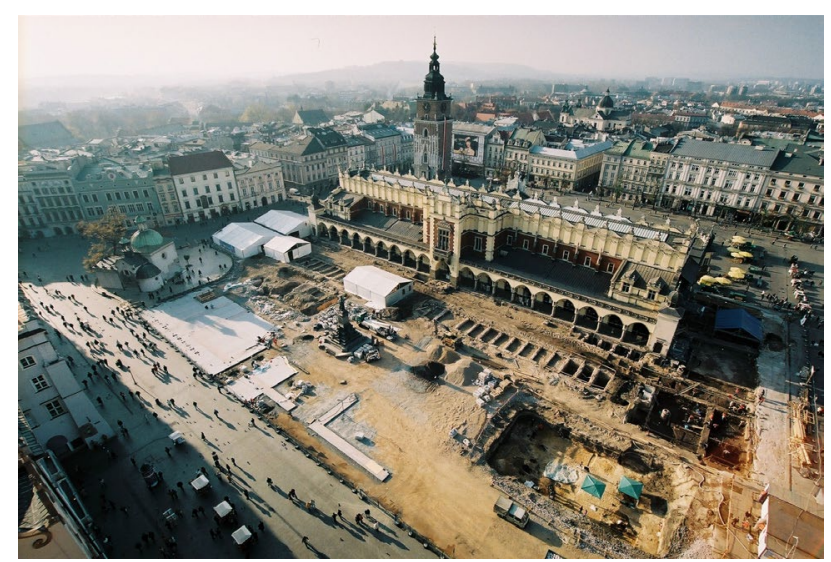

Fig. 1. Archaeological excavation at the Main Market Square in Kraków. we are dealing with a funeral rite dictating inhumation in rows. A burial pit was usually intended for a single individual, but the occasional double burial was found. Often coffins were recorded in the burial pits.

The basic organization principle of the necropolis was, as is typical of similar cemeteries from other parts of Poland, the laying of graves in rows along a North-South axis (Zoll-Adamikowa, 1971). The majority of the burials were oriented, in accordance with the Christian rites, along an East-West axis (with the head pointing to the West) (Dzik, 2006). The dead were laid in a supine position with their upper limbs alongside their torsos. However a significant number of those found at this burial site depart markedly from these principles. Here can be noted a concentration of graves at right angles to each other or radiating out in different directions, heads pointed to the east and bodies laid along a North-South axis in a crouched position or on their stomachs. The manner of laying the upper limbs of the deceased also displays significant variation.

\section{MATERIAL}

Fragments of the compact bone were extracted from diaphysis of femur taken from 65 individuals, including 11 children and 54 adults ( 22 men and 32 women), whose remains had been uncovered at the early mediaeval cemetery located at the Main Market Square in Kraków. All individuals were recovered from the same type of graves (wooden coffin; East-West orientation of skeletons). Five of them were in shared graves (grave no. 2288: 3 individuals and grave no. 963: 2 individuals).

Age of individuals was estimated on the basis of dental development and epiphyseal closure (in children) as well as cranial suture closure, changes on the surface of the pubic symphysis and the rate of tooth wear (in adults) (Buikstra and Ubelaker, 1994; White and Folkens, 2005). Sex was determined primarily on the basis of the pelvic form, i.e., greater sciatic notch and subpubic morphology, supplemented with cranial features (Acsádi and Nemeskéri, 1970; Bruzek and Murail, 2006; Buikstra and Ubelaker, 1994).

The research covered individuals who were more than 5 years old at the time of death, for it is assumed that the youngest children were breastfed, which could have represented an extra factor conditioning the oxygen isotope ratios in bone (Stepańczak et al., 2011). Given the biological and cultural aspects of the weaning process, children over five were probably not breastfed (Richards et al., 2002).

When using bone in isotope research, it should be taken into account that bone undergoes continuous histological and elemental remodelling. The pace of this process with regard to the compact bone of long bones reaches $4-8 \%$ /year in adult individuals, which means that that the oxygen isotope composition indicated in this tissue represents the final years of life of the investigated 
individuals (Manolagas, 2000; Ruff and Hays, 1988). In children, the process is faster due to the intense pace of bone development, growth and modelling, lasting about a year, and only a few months in the case of newborns (Parfitt et al., 2000; Turner et al., 2007; Williams et al., 2005).

\section{METHOD}

In order to conduct analyses of the bone material, the fragments of compact bone taken from the skeletons were washed in an ultrasonic cleaner, dried and ground in a ball mill.

During the first stage of research, it was necessary to carry out an accurate assessment of the degree of advancement of diagenetic changes in the mineral structure of the bone material, since the isotope analysis covered skeletal remains from the medieval period. For this reason, each bone sample was subjected to analysis by means of the infrared spectroscopy method using the Fourier transform (FTIR, Fourier Transform-Infrared Spectrometer) in accordance with the methodology proposed by Wright and Schwarz (1996). For every bone, a spectrum in the mid infrared range (from $4000 \mathrm{~cm}^{-1}$ to $400 \mathrm{~cm}^{-1}$ ) was attained in the form of an absorption dependency function from radiated energy expressed using a wavenumber $\left(\widetilde{v}\left[\mathrm{~cm}^{-1}\right]\right)$. The spectral analysis was conducted using the Essential FTIR v 2.00.040 software.

On the basis of the spectra, two indicators were applied to assess diagenetic alteration of the samples - the Crystallinity Index:

$\left.C I=\left(A_{565}+A_{605}\right) / A_{595}\right)$

and the carbonate/phosphate indicator:

$\mathrm{CO}_{3} / \mathrm{PO}_{4}=A_{1415} / A_{1035}$

where $A_{\mathrm{x}}$ denotes the band intensity (peak height) at a given wavenumber $(x)$, respectively $565 \mathrm{~cm}^{-1}\left({ }_{v 4} \mathrm{PO}_{4}\right)$, $605 \mathrm{~cm}^{-1} \quad\left({ }_{v 4} \mathrm{PO}_{4}\right), \quad 1035 \mathrm{~cm}^{-1} \quad\left({ }_{v 3} \mathrm{PO}_{4}\right)$ and $1415 \mathrm{~cm}^{-1}$ $\left({ }_{23} \mathrm{CO}_{3}\right)$, as well as the narrowing around $\sim 590 \mathrm{~cm}^{-1}$ occurring between bands 565 and $605 \mathrm{~cm}^{-1}$ (Lebon et al., 2010; Wright and Schwarcz, 1996).

During the next stage, analysis of stable oxygen isotopes was conducted on phosphorus groups isolated from the bone apatite. Approximately $40 \mathrm{mg}$ of cortical bone samples were pretreated using $2 \% \mathrm{NaOCl}, 0.125 \mathrm{M} \mathrm{NaOH}$ and $2 \mathrm{M} \mathrm{HF}$ to remove organic material and calcium. The phosphate of the samples was precipitated as silver phosphate crystals $\left(\mathrm{Ag}_{3} \mathrm{PO}_{4}\right)$ by adding $15 \mathrm{ml}$ of the silver nitrate solution $\left(\mathrm{AgNO}_{3}\right)$ (Grimes and Pellegrini, 2013; Stephan, 2000). The oxygen isotope ratios of $\mathrm{Ag}_{3} \mathrm{PO}_{4}$ crystals were measured at the Radioisotope Laboratory at the Silesian University of Technology in Gliwice, using elemental analyzer coupled to the IsoPrime continuous flow isotope ratio mass spectrometer. Each sample was analysed in triplicate and the results were averaged.
Silver phosphate prepared from an NIST 120c sample was used as an oxygen isotope composition standard. During the calculations, a $\delta^{18} \mathrm{O}$ for NIST $120 \mathrm{c}$ equal to $21.7 \%$ in relation to the VSMOW scale was adopted as a benchmark (Chenery et al., 2010; Lécuyer et al., 2007). All $\delta^{18} \mathrm{O}$ results were expressed on the VSMOW scale (Coplen, 1994).

All statistical analyses were conducted using Stagraphics Centurion XV software. The Pearson's correlation coefficient $(r)$ and the coefficient of determination $\left(R^{2}\right)$ were used to test linear relationship between variables. In order to assess significance of the correlation coefficient the level of statistical significance $(p)$ was calculated.

\section{RESULTS}

All the results of the conducted analyses for the samples taken from the investigated individuals have been listed in Table 1.

\section{Diagenesis}

According to the data available in the literature, the $C I$ value for bones should not exceed 3.6 if it is to be assumed that the bone material has not undergone significant re-crystallisation (Berna et al., 2004; Szostek et al., 2011; Wright and Schwarcz, 1996). In the case of the $\mathrm{CO}_{3} / \mathrm{PO}_{4}$ indicator, results exceeding the $0.15-0.7$ range indicate changes in the mineral portion of the osteological material. $\mathrm{CO}_{3} / \mathrm{PO}_{4}$ indicator values below 0.15 indicate degradation of the fraction of biogenic carbonates or the incorporation into the crystalline network of secondary apatites with a low carbonate content, e.g. francolite. In contrast, too high values of the $\mathrm{CO}_{3} / \mathrm{PO}_{4}$ indicator would suggest that the samples have been contaminated by calcite (Nagy et al., 2008; Yoder and Bartelink, 2010).

The $C I$ values of the investigated bone samples were within the 2.64-3.43 range and those of the $\mathrm{CO}_{3} / \mathrm{PO}_{4}$ indicator within the $0.19-0.53$ range. Therefore, there was no record of any bone sample exceeding the permissible range both in respect of $C I$ index and $\mathrm{CO}_{3} / \mathrm{PO}_{4}$ indicator values, which suggests that the mineral structure during life had been preserved in all cases.

In order to ascertain whether potential diagenetic changes impacted on the oxygen isotope proportions in the bone, tests were carried out to check for the existence of a relationship between the $C I$ index and the oxygen isotope composition $\left(\delta^{18} \mathrm{O}\right)$ of the collected bone and dental tissue samples. An analogous relationship for the $\mathrm{CO}_{3} / \mathrm{PO}_{4}$ indicator was also tested for. Analysis of correlations between the above diagenetic parameters and the oxygen isotope composition of the researched tissues samples is regarded by many researchers as an important indicator when the diagenesis of skeletal material is being researched (Dupras and Schwarcz, 2001; Spence et al., 2004; Wright and Schwarcz, 1996). Pearson correlation analysis failed to reveal any significant relationship be- 
Table 1. The results of $\delta^{18} \mathrm{O}(\%, \mathrm{VSMOW}), \mathrm{Cl}$ and the $\mathrm{CO}_{3} / \mathrm{PO}_{4}$ indicator in bone apatite of individuals buried in a burial ground in Main Market Square in Kraków. F-female, $M$ - male.

\begin{tabular}{|c|c|c|c|c|c|c|c|c|c|c|c|c|c|}
\hline No. & Grave no. & Sex & Age (years) & $\delta^{18} 0$ & $\mathrm{Cl}$ & $\mathrm{CO}_{3} / \mathrm{PO}_{4}$ & No. & Grave no. & Sex & Age (years) & $\delta^{18} 0$ & $\mathrm{Cl}$ & $\mathrm{CO}_{3} / \mathrm{PO}_{4}$ \\
\hline \multicolumn{7}{|c|}{ Adults } & \multicolumn{7}{|c|}{ Adults } \\
\hline 1 & 1 & $\mathrm{~F}$ & 30 & 16.32 & 2.75 & 0.43 & 35 & 2288 & M & 40 & 14.04 & 3.06 & 0.32 \\
\hline 2 & 4 & M & 40 & 15.42 & 3.02 & 0.30 & 36 & 2288 & $\mathrm{~F}$ & 30 & 14.46 & 3.14 & 0.28 \\
\hline 3 & 5 & M & 30 & 15.21 & 2.80 & 0.43 & 37 & 2294 & M & 35 & 13.89 & 3.24 & 0.26 \\
\hline 4 & 6 & $\mathrm{~F}$ & 35 & 15.59 & 3.14 & 0.30 & 38 & 2304 & M & 30 & 15.49 & 3.21 & 0.28 \\
\hline 5 & $9 a$ & $\mathrm{~F}$ & 30 & 15.99 & 2.99 & 0.35 & 39 & 2323 & $\mathrm{~F}$ & 30 & 17.77 & 3.01 & 0.30 \\
\hline 6 & 11 & $F$ & 70 & 13.74 & 3.24 & 0.22 & 40 & 2364 & $F$ & 35 & 17.99 & 2.81 & 0.35 \\
\hline 7 & 13 & M & 30 & 15.09 & 2.85 & 0.41 & 41 & 2373 & M & 60 & 14.73 & 3.19 & 0.27 \\
\hline 8 & 15 & M & 50 & 13.93 & 2.74 & 0.45 & 42 & 2398 & $\mathrm{~F}$ & 55 & 14.94 & 2.85 & 0.41 \\
\hline 9 & 18 & M & 40 & 16.15 & 2.86 & 0.38 & 43 & 2426 & $\mathrm{~F}$ & 45 & 16.76 & 2.93 & 0.38 \\
\hline 10 & 19 & $\mathrm{~F}$ & 40 & 14.86 & 3.05 & 0.30 & 44 & 2462 & M & 45 & 15.84 & 3.26 & 0.24 \\
\hline 11 & 27 & $\mathrm{~F}$ & 30 & 15.82 & 2.64 & 0.52 & 45 & 2492 & $\mathrm{~F}$ & 35 & 15.94 & 3.27 & 0.26 \\
\hline 12 & 31 & M & 35 & 16.38 & 2.91 & 0.42 & 46 & 2571 & M & 40 & 15.93 & 3.21 & 0.28 \\
\hline 13 & 35 & $\mathrm{~F}$ & 40 & 16.29 & 2.64 & 0.53 & 47 & 2584 & $\mathrm{~F}$ & 35 & 14.28 & 3.32 & 0.22 \\
\hline 14 & 209 & M & 30 & 16.85 & 2.78 & 0.40 & 48 & 2590 & $\mathrm{~F}$ & 25 & 15.18 & 2.91 & 0.37 \\
\hline 15 & 364 & M & 30 & 18.91 & 2.87 & 0.35 & 49 & 2593 & M & 50 & 14.34 & 3.43 & 0.38 \\
\hline 16 & 446 & $M$ & 50 & 14.74 & 3.16 & 0.29 & 50 & 2603 & $\mathrm{~F}$ & 55 & 15.45 & 2.65 & 0.49 \\
\hline 17 & 490 & M & 40 & 17.32 & 3.17 & 0.31 & 51 & 2607 & M & 50 & 16.97 & 2.78 & 0.39 \\
\hline 18 & 963 & $\mathrm{~F}$ & 30 & 13.52 & 2.80 & 0.44 & 52 & $2609 a$ & $\mathrm{~F}$ & 50 & 13.74 & 3.03 & 0.26 \\
\hline 19 & 963 & $\mathrm{~F}$ & 40 & 15.67 & 2.76 & 0.40 & 53 & 2611 & M & 55 & 14.59 & 2.84 & 0.38 \\
\hline 20 & 1115 & $\mathrm{~F}$ & 55 & 12.23 & 3.09 & 0.38 & 54 & 2676 & $\mathrm{~F}$ & 35 & 14.95 & 3.41 & 0.19 \\
\hline 21 & 1290 & $\mathrm{~F}$ & 40 & 17.11 & 3.25 & 0.26 & & & & & & & \\
\hline 22 & 1491 & $\mathrm{~F}$ & 20 & 14.10 & 2.96 & 0.36 & \multicolumn{7}{|c|}{ Children } \\
\hline 23 & 1522 & $\mathrm{~F}$ & 25 & 14.75 & 3.22 & 0.23 & 55 & 10 & - & 8 & 14.26 & 2.89 & 0.39 \\
\hline 24 & 1523 & $\mathrm{~F}$ & 30 & 12.50 & 2.83 & 0.41 & 56 & 23 & - & 9 & 13.87 & 3.12 & 0.25 \\
\hline 25 & 1739 & $\mathrm{~F}$ & 70 & 12.37 & 3.22 & 0.36 & 57 & 25 & - & 5 & 15.82 & 2.90 & 0.43 \\
\hline 26 & 1795 & $F$ & 30 & 17.85 & 2.82 & 0.36 & 58 & 1547 & - & 10 & 18.44 & 3.15 & 0.38 \\
\hline 27 & 1876 & $M$ & 60 & 15.55 & 2.79 & 0.42 & 59 & 1872 & - & 5 & 16.37 & 2.79 & 0.47 \\
\hline 28 & 1956 & $F$ & 40 & 15.60 & 3.04 & 0.45 & 60 & 1920 & - & 14 & 14.10 & 3.11 & 0.29 \\
\hline 29 & 1958 & $\mathrm{~F}$ & 30 & 15.42 & 2.88 & 0.40 & 61 & 2319 & - & 7 & 16.52 & 3.06 & 0.32 \\
\hline 30 & 1978 & $M$ & 30 & 15.03 & 3.03 & 0.29 & 62 & 2360 & - & 5 & 15.56 & 2.93 & 0.31 \\
\hline 31 & 2038 & $M$ & 30 & 14.37 & 2.89 & 0.33 & 63 & 2443 & - & 10 & 15.85 & 3.14 & 0.28 \\
\hline 32 & 2116 & $\mathrm{~F}$ & 35 & 16.73 & 2.85 & 0.42 & 64 & 2596 & - & 9 & 15.63 & 3.12 & 0.25 \\
\hline 33 & 2132 & $F$ & 35 & 15.30 & 3.11 & 0.36 & 65 & NN1 & - & 8 & 16.15 & 2.89 & 0.37 \\
\hline 34 & 2288 & $\mathrm{~F}$ & 35 & 14.53 & 3.02 & 0.31 & & & & & & & \\
\hline
\end{tabular}

tween the $C I$ and $\delta^{18} \mathrm{O}$ level $(p=0.07)$ or between the $\mathrm{CO}_{3} / \mathrm{PO}_{4}$ indicator and $\delta^{18} \mathrm{O}$ level $(p=0.27)$. The results show that any potential post mortem changes in the samples that were taken were insignificant from the perspective of spectrometric oxygen isotope analysis of the phosphate apatites.

\section{Oxygen Isotope Analysis}

The main objective of this study was an analysis of the relationship between the level of oxygen isotopes contained in bone phosphates and the age of studied individual. It allowed assessing the homogeneity of the analysed group and similarity of its characteristics with the local population. The bone $\delta^{18} \mathrm{O}$ value was referenced to the isotopic level in precipitation occurring over Kraków area. In the case of Polish territory, particularly the southern part of the country, the variability of ratio of oxygen isotopes notified in case of precipitation water is high and due to both diverse climate (hot summer months, cold winter months) and specific topography of the terrain (uplands and valleys). In the area of Kraków, the average of oxygen isotope ratio in precipitation water amounts to $-9.83 \%$ with standard deviation of $3.27 \%$.

Long-term measurements of the oxygen isotopes ratio in precipitation water were made within the project - the Global Network of Isotopes in Precipitation (GNIP) - in a station located in Kraków's district (Wola Justowska) about $5 \mathrm{~km}$ away from the Main Market Square (Fig. 2). Results are made available by The International Atomic Energy Agency (IAEA, 2001).

The range of variability of oxygen isotope level occurring in Kraków area was established based on the value of two standard deviations (Roberts et al., 2013) resulting in local level between -16.37 and $-3.29 \%$. This range corresponds to a $\delta^{18} \mathrm{O}$ range of bone phosphate from 12.07 to 19.63\%o (Daux et al., 2008). The use of oxygen isotopes to determine migration is based on the relationship between oxygen isotope composition of human bone and contemporary isotopic variation in its 


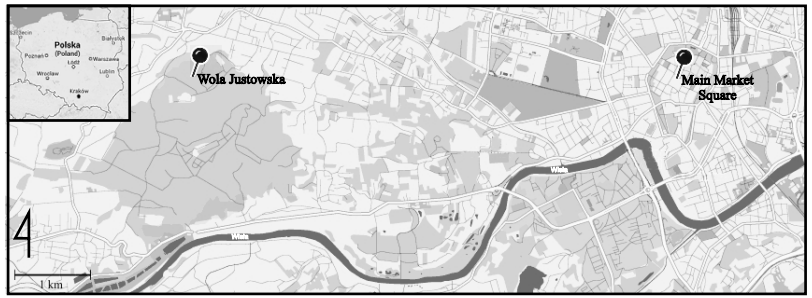

Fig. 2. Map of Kraków showing the location of the early medieval cemetery (Main Market Square) and station where samples of precipitation water were collected (Wola Justowska).

content in the precipitation within the study region. All results were within the range of local value, hence analysed individuals were considered as residents of Kraków (Fig. 3). Moreover, no differences were observed in the level of oxygen isotopes found in individuals buried in shared graves and in individual graves.

In order to assess the relationship between the oxygen isotope value in bone phosphate and an individual's age, regression analysis was used. The conducted analysis revealed the existence of a linear negative correlation between the above parameters $\left(r=-0.28 ; R^{2}=7.90 \%\right)$, which appeared to be statistically significant $(p=0.02)$. It should be noted that no influential point was identified to significantly affect the slope of the regression line. The outcome of the analysis is presented in Fig. 4.

To verify the direction of relationship in the context of age and sex of the studied individuals, further analyses were conducted. In a case of females, the age of the individual seems to be important in the determination of $\delta^{18} \mathrm{O}$ ratio in bone $\left(r=-0.39 ; R^{2}=15.14 \% ; p=0.03\right)-$ the older the individual is, the lower oxygen isotope value in bone is (Fig. 5). In males, the correlation is not statistically significant $(p=0.26)$.

Tests were therefore also conducted to ascertain the nature of the relationship between the $\delta^{18} \mathrm{O}$ level in the long bones and the age of individuals in the following age brackets: 1) $<40$ years and 2) $\geq 40$ years. Analyses were conducted separately for women and men. A regression line was again adapted to fit each of the allotted groups and in both cases a straight-line relationship was affirmed. In the case of the group of individuals under 40 years of age, the relationship between the investigated parameters turned out to be statistically insignificant for both males $\left(r=-0.21 ; R^{2}=4.36 \% ; p=0.60\right)$ and females $\left(r=0.24 ; R^{2}=5.63 \% ; p=0.31\right)$. Also in men older than 40 years no statistically significant correlation between $\delta^{18} \mathrm{O}$ ratio and age was noted. However, in women representing the oldest age classes (the group over 40 years of age), a negative correlation $\left(r=-0.81 ; R^{2}=65.47 \%\right)$ was observed, which was revealed to be statistically significant ( $p=0.0014)$ (Fig. 6). It should also be stressed that none of the above analyses showed an element significantly altering the shape of regression line (influence points).

Differences in isotopic composition of oxygen in bone phosphate between the oldest female individuals and the remaining part of the group were shown also by multivariant cluster analysis (using group average method) (Fig. 7). The three oldest women were distinguished as a separate cluster (cluster 2) and had the lowest values of $\delta^{18} \mathrm{O}$ in bone phosphate which significantly diverged from the mean value of cluster 1 . The youngest individuals (within age groups of infans I and infans II) did not differ significantly in this respect from adult individuals (in age groups of adultus and maturus).

A biodemographic analysis of people deceased in the prelocational Kraków conducted by Głąb et al. (2010) showed that the age structure of the studied group is closest to that of a progressively developing population (Rosset, 1959). Among the deceased there was a high proportion $(49.7 \%)$ of children ( $0-14 \mathrm{yrs})$ and low proportion (around $5 \%)$ of elders $(\geq 60 \mathrm{yrs})$. These results are supported by the historical and economical characteristic of Kraków as a city dynamically developing in early Middle Ages. It should be added that such a low proportion of individuals from the senilis category is typical also for other medieval populations from the area of Poland and

Fig. 3. $\delta^{18} \mathrm{O}$ values of bones of all individuals relate to the local precipitation level.

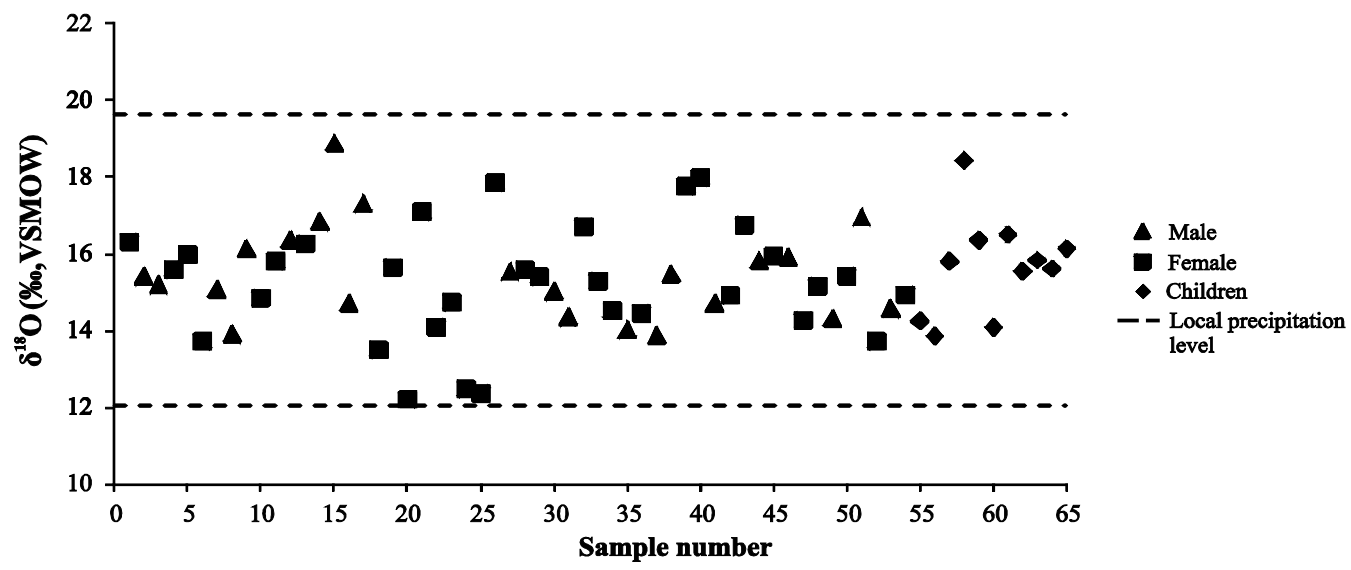




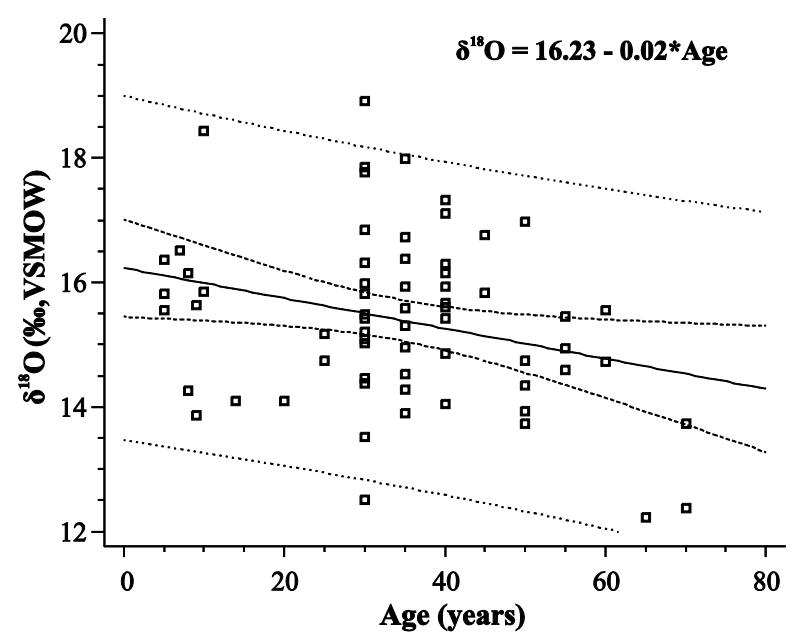

Fig. 4. The relationship between $\delta^{18} \mathrm{O}$ in the long bones of men and women and an individual's age. The lines represent: the regression line (the straight line) given by equation: $\delta^{18} \mathrm{O}=16.23-0.02 \times A g e$, the $95 \%$ confidence interval (dashed lines) and the prediction interval (dotted lines).

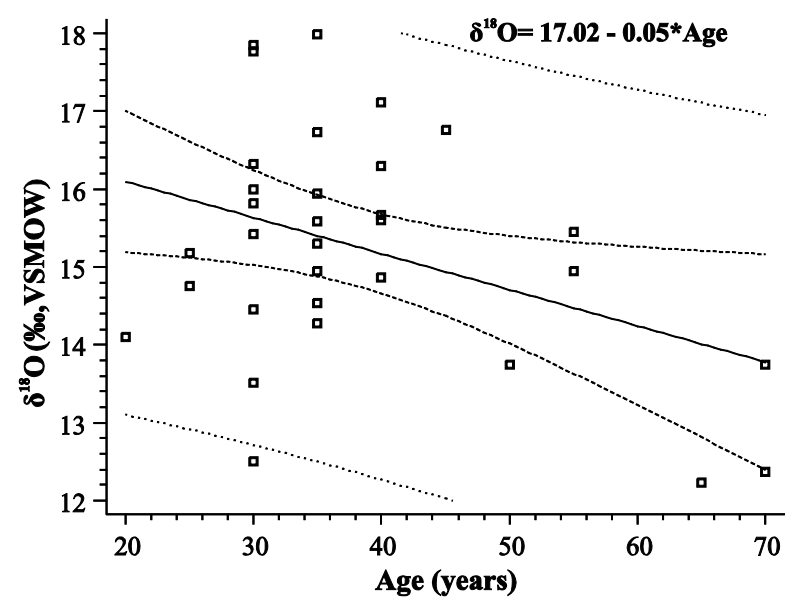

Fig. 5. The relationship between $\delta^{18} \mathrm{O}$ in the long bones of women and an individual's age. The lines represent: the regression line (the straight line) given by equation: $\delta^{18} \mathrm{O}=17.02-0.05 \times$ Age, the $95 \%$ confidence interval (dashed lines) and the prediction interval (dotted lines).

ranges from 1.5 to $9.3 \%$ (Lubocka and Gronkiewicz, 2006). Among specimens studied in the present work the proportion of older people amounted to $8 \%$, thus it can be claimed that regarding the age structure the group is characteristic for this period and representative in the context of proportions of individuals in particular age groups. However, the authors are aware that small size of studied sample might affect the statistical analyses, thus the above results should be treated with caution and as preliminary.

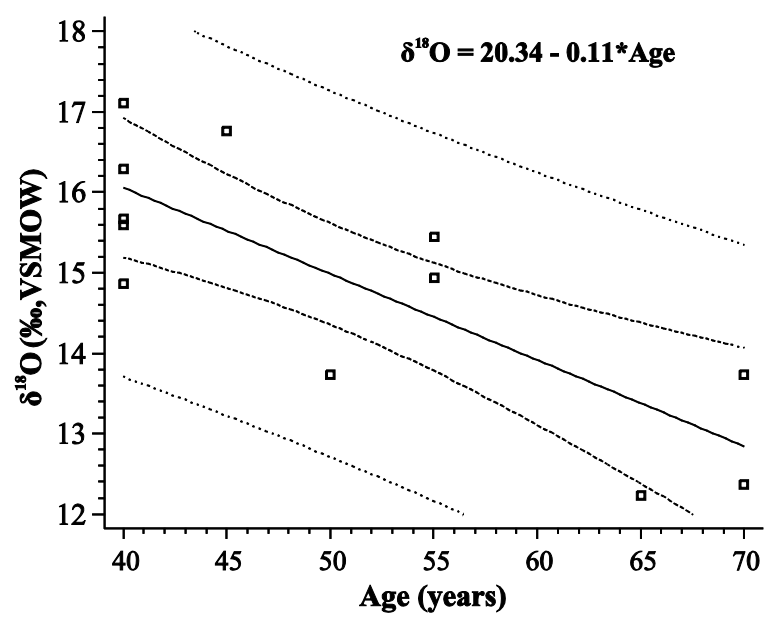

Fig. 6. The relationship between $\delta^{18} \mathrm{O}$ in the long bones of women and an individual's age $\geq 40$ years. The lines represent: the regression line (the straight line) given by equation: $\delta^{18} \mathrm{O}=20.34-0.11 \times$ Age, the $95 \%$ confidence interval (dashed lines) and the prediction interval (dotted lines).

\section{DISCUSSION}

Research carried out on various species of animal has shown the variable level of $\delta^{18} \mathrm{O}$ in tissues is not only dependent on environmental factors, but also on the organism's physiological conditioning (White et al., 2004b). A particularly strong correlation has been observed between the $\delta^{18} \mathrm{O}$ ratio and the rate of metabolic changes occurring in the body, which are chiefly linked, in turn, with body weight. Small animals characterized by swift metabolism are notable for their low levels of $\delta^{18} \mathrm{O}$ in comparison with large animals with a significantly slower metabolism (assuming, of course, that they are consuming water with an identical oxygen isotope composition) (Bryant and Froelich, 1995). The metabolic rate changes at different stages of a person's development, while the fastest oxygen metabolism rate is observed in children, due to the process of continuous growth occurring within them, as well as the intensive development of their systems and organs (Armon et al., 1991). This fact would suggest the occurrence of a lower oxygen isotope level in children's bones in comparison with those of adult individuals. The cluster analysis showed that no significant difference was found between the $\delta^{18} \mathrm{O}$ level of bone phosphate in children and adults (Fig. 7).

The influence of the developmental processes connected with changes in body size on the oxygen isotope ratios in skeletal material has been investigated by Kirsanow and Tuross (2011). The authors of this paper used rats as animal models. They were bred under controlled laboratory conditions and given water containing a constant $\delta^{18} \mathrm{O}$ ratio. The research showed that the oxygen isotope level in tooth enamel does not change with age in rats (a rat's teeth grow throughout its life). Moreover, an 


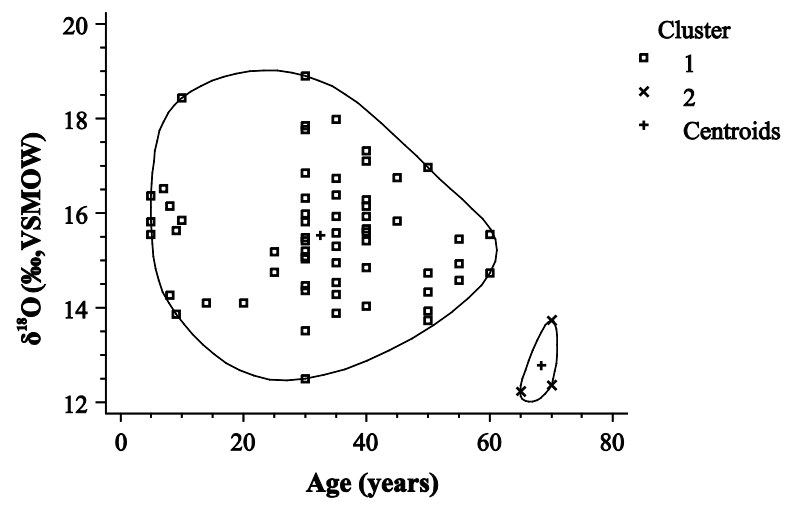

Fig. 7. Oxygen isotopic composition of bones of analysed individuals within age clusters. The majority of older individuals are members of cluster 2 compared to cluster 1 including younger individuals.

analysis of the oxygen isotope level in the bone apatite of pigs conducted by Warinner and Tuross (2010) showed that there was no significant difference in the $\delta^{18} \mathrm{O}$ values of bone tissue in animals with a normal and reduced rate of organism growth. It can therefore be assumed that in the case of human beings as well, any differences arising from body size and the organism's changing growth rate at various stages of ontogenesis do not have a significant impact on the oxygen isotope composition in teeth and bones. Also, Kohn (1996) does not agree with the massdependent effect postulated by Bryant and Froelich (1995). According to Kohn's model behavioral and physiological factors, such as amount of daily water input and output, as well as mechanisms of thermoregulation, are the most important parameters affecting the $\delta^{18} \mathrm{O}$ value in organisms.

In the present study we suggest that the variability of isotopic level of an organism, besides the well-known factors like climate, migrations or diet (Budd et al., 2004), might be influenced by physiological changes occurring in the organism, and related to the process of involution. The conducted correlation analysis prompted the observation that after 40 years of life, the oxygen isotope level in bone tissue significantly drops as an individual increases in age (Fig. 6). The causes of this phenomenon may be linked with involutional processes within an organism and progressive changes in bone tissue. Under physiological conditions, the activity state of osteoclasts and osteoblasts during elemental bone remodelling remains in a state of dynamic equilibrium (Hadjidakis and Androulakis, 2006; Ruimerman, 2005). However, there are factors which can disrupt the homeostasis of this process, and then osteoresorption begins to gain an advantage over the synthesis of bone tissue. This phenomenon can be observed in the case of anaemia, hormonal disorders and other illnesses affecting the ionic homeostasis of the organism, as well as during pregnancy and lactation (Martin and Armelagos, 1985; Mulhern and Van
Gerven, 1997). Numerous studies indicate that the bone resorption processes which are already beginning around 30 years of age intensify considerably after 45 years of age, leading to a gradual loss of bone mass - at an average of $1-2 \%$ a year in women (Manolagas and Parfitt, 2010). Lower value of $\delta^{18} \mathrm{O}$ might reflect a higher frequency and sharpness of osteopenia in elder women (White et al., 2004a). After 50 years of life, i.e. during the perimenopausal period, the tempo of this process significantly increases and can even reach a rate of $4-8 \%$ per year in spongy bone and $2-3 \%$ in compact bone, frequently leading to osteoporotic changes (Manolagas, 2000). It is true that the literature contains no proof of the existence of a relationship between the above phenomenon and the oxygen isotope concentration in bones, but an analysis of stable nitrogen isotopes conducted by Fuller et al. (2004) on hair taken from modern women revealed a level of less than $0.5-1 \%$ during pregnancy and lactation. Researchers suppose that similar phenomena may occur in bones and directly link them with the heightened resorption of bone tissue in this period, which can even reach 3-5\% (Kalkwarf and Specker, 2002; Prentice, 2000). The period devoted to pregnancy and breastfeeding is relatively short in comparison with the time required for elemental bone remodelling, so observation of any change in the oxygen isotope proportions in bone tissue linked to a period of pregnancy is difficult. However, we cannot exclude the possibility that if a women has multiple children over the course of several years (which, had been common among medieval populations) then we would expect to reveal the effects of pregnancy and nursing in adult women.

Other possible explanation for this observation concerns an activity level of older people. In older people, oxygen uptake decreases with age as a result of less intensive lung ventilation and physical activity (Żołądź et al., 2011). Widory (2004) demonstrated that oxygen fractionation increases with decreased activity level, probably due to decreased oxygen diffusion through the pulmonary membranes, hart rate and water vapour loss. Thus, the oxygen pool in organism of less physically active people is characterized by an increased amount of the lighter ${ }^{16} \mathrm{O}$ isotope in relation to its heavier form. Moreover, a decrease of $\delta^{18} \mathrm{O}$ ratio was observed by Reitsema and Crews (2011) in bones of transgenic laboratory mice expressing human sickle-cell disease (SDC) globins which demonstrated less activity level. Hence, we can expect a reduction of ${ }^{18} \mathrm{O}$ in bone of the elderly in relation to younger, more active people. In addition, Widory (2004) found that older individuals had lower normalized amplitude of the $\mathrm{O}_{2}$ isotope fractionation $(\mathrm{Z})$. This phenomenon is probably linked to the $\mathrm{O}_{2}$ fixation rate which increases with the age. Consequently, this leads to higher values of the $\delta^{18} \mathrm{O}$ in exhaled air and the fraction of $\mathrm{O}_{2}$ used. The results of our analyses do not contradict the findings of the above research. 
Additionally, age differences have been noted in sweating rate (Crowe and Moore, 1974; Kenney and Munce, 2003). Many studies indicate that the older people sweat less than younger subjects what is probably caused by a weakened activity of the sweat glands (Kenney and Munce, 2003). In addition, the reduction in the sweating activity is more pronounced in aged females. During sweating, a preferential loss of lighter oxygen isotopes $\left({ }^{16} \mathrm{O}\right)$ occurs. Thus, in elderly people, less physically active and less sweating, it comes to a greater retention of lighter isotopes in the organism as compared with younger aged groups. Moreover, transcutaneous isotopic fractionation, probably, decreased in older individuals with thinner skin, causing a decreased $\delta^{18} \mathrm{O}$, qualitatively similar to the observed trend.

One should also consider the fact that older individuals in medieval times could eat different foods than younger people. Daux et al. (2008) show up to $2 \%$ effects of diet on $\delta^{18} \mathrm{O}$. The diet of inhabitants of the earlymedieval Kraków was probably not very diverse, as evidenced by the analysis of plant and animal remains explored at the cemetery. The diet included mainly farm animals like cows, sheep, pigs or chickens, as well as cereals, such as millet, rye or wheat (Mueller-Bieniek, 2010; Wojtal et al., 2010). However, there is no any clear evidence that the diet of the elderly significantly differed from the diet of the younger inhabitants of prelocational Kraków. This problem, however, demands more detailed study with carbon and nitrogen isotopes.

It should be borne in mind that the analysis conducted for the needs of this paper is based on a relatively small sample (there was a particularly small number of individuals over fifty years of age). Moreover, when using archaeological material in research, the possibility of committing an error when estimating the age of adult individuals should be taken into account, particularly when remains are in a poor state of preservation (Jerszyńska, 2004). The initial research findings presented in this paper suggest a need to undertake further research related to the influence an individual's age has on oxygen isotope concentrations in bone tissue. All the more so since the results of these investigations could be related to the interpretation of $\delta^{18} \mathrm{O}$ results for bone tissue taken from older individuals within a migration research context.

\section{CONCLUSION}

The correlation analysis results suggest that the results of the analysis of stable oxygen isotopes should be treated with great caution, for the $\delta^{18} \mathrm{O}$ of the long bones was attained for people over forty years of age within the context of migration research. The oxygen isotope level in bone tissue among these people may be the outcome not only of environmental factors but also involutional changes in bone linked to an organism's ageing. This problem does not apply to $\delta^{18} \mathrm{O}$ measurements in tissue coming from teeth, because, unlike bone tissue, it is not subject to elemental remodelling. These preliminary studies will be continued.

\section{REFERENCES}

Acsádi G and Nemeskéri J, 1970. History of human life span and mortality. Akadémiai Kiadó, Budapest.

Akkus O, Polyakova-Akkus A, Adar F and Schaffler MB, 2003. Aging of Microstructural Compartments in Human Compact Bone. Journal of Bone and Mineral Research 18: 1012-1019, DOI 10.1359/jbmr.2003.18.6.1012.

Arlot ME, Meunier PJ, Boivin G, Haddock L, Tamayo JA, CorreaRotter R, Jasqui S, Donley DW, Dalsky GP, Martin JS and Eriksen EF, 2005. Differential effects of teriparatide and alendronate on bone remodeling in postmenopausal women assessed by histomorphometric parameters. Journal of Bone and Mineral Research 20: 1244-1253, DOI 10.1359/JBMR.050309.

Armon Y, Cooper D, Flores R, Zanconato S and Barstow TJ, 1991. Oxygen uptake dynamics during high-intensity exercise in children and adults. Journal of Applied Physiology 70: 841-848.

Benson S, Lennard C, Maynard P and Roux C, 2006. Forensic applications of isotope ratio mass spectrometry-a review. Forensic Science International 157: 1-22, $\quad$ DOI 10.1016/j.forsciint.2005.03.012.

Bergot C, Wu Y, Jolivet E, Zhou LQ, Laredo JD and Bousson V, 2009. The degree and distribution of cortical bone mineralization in the human femoral shaft change with age and sex in a microradiographic study. Bone 45: 435-442, DOI 10.1016/j.bone.2009.05.025.

Berna F, Matthews A and Weiner S, 2004. Solubilities of bone mineral from archaeological sites: the recrystallization window. Journal Archaeological Science 31: 867-882, DOI 10.1016/j.jas.2003.12.003.

Bowen GJ and Wilkinson B, 2002. Spatial distribution of $\delta^{18} \mathrm{O}$ in meteoric precipitation. Geology 30: 315-318, DOI 10.1130/00917613(2002)030<0315:SDOOIM $>2.0$. CO;2.

Britton K, Grimes V, Dau J and Richards MP, 2009. Reconstructing faunal migrations using intra-tooth sampling and strontium and oxygen isotope analyses: a case study of modern caribou (Rangifer tarandus granti). Journal of Archaeological Science 36: 11631172, DOI 10.1016/j.jas.2009.01.003.

Bruzek J and Murail P, 2006. Methodology and reliability of sex determination from the skeleton. In: Schmitt A, Cunha E and Pinheiro J, eds., Forensic anthropology and medicine: complementary sciences from recovery to cause of death. Totowa: Humana Press Inc, 225-242.

Bryant J and Froelich PN, 1995. A model of oxygen isotope fractionation in body water of large mammals. Geochimica Cosmochimica Acta 59: 4523-4537, DOI 10.1016/0016-7037(95)00250-4.

Budd P, Millard A, Chenery C, Lucy S and Roberts C, 2004. Investigating population movement by stable isotope analysis: a report from Britain. Antiquity 78(299): 127-141.

Buikstra JE and Ubelaker DH (eds.), 1994. Standards for data collection from human skeletal remains. Arkansas Archeological Survey, Fayetteville, Ark.

Chenery C, Müldner G, Evans J, Eckardt H and Lewis M, 2010. Strontium and stable isotope evidence for diet and mobility in Roman Gloucester, UK. Journal of Archaeological Science 37: 150-163, DOI 10.1016/j.jas.2009.09.025.

Coplen TB, 1994. Reporting of stable hydrogen, carbon, and oxygen isotopic abundances. Pure Applied Chemistry 66: 273-276, DOI 10.1351/pac199466020273.

Crowe JP and Moore RE, 1974. Proceedings: Physiological and behavioral responses of aged men to passive heating. The Journal of Physiology 236(1): 43-45.

Daux V, Lécuyer C, Héran MA, Amiot R, Simon L, Fourel F, Martineau F, Lynnerup N, Reychler H and Escarguel G, 2008. Oxygen isotope fractionation between human phosphate and water revisit- 
ed. Journal of Human Evolution 55: 1138-1147, DOI 10.1016/j.jhevol.2008.06.006.

Dupras TL and Schwarcz HP, 2001. Strangers in a strange land: stable isotope evidence for human migration in the Dakhleh Oasis, Egypt. Journal of Archaeological Science 28: 1199-1208, DOI 10.1006/jasc. 2001.0640 .

Dzik M, 2006. Wczesnośredniowieczne cmentarzysko w Żukowie. (Early medieval burial ground in Żuków) In: Lewartowski K, ed. ŚWIATOWIT Supplement Series P: Prehistory and Middle Ages, vol. XIII. Warszawa, (in Polish).

Eastoe JE, 1956. The organic matrix of bone. In: Bourne GH, ed. Biochemistry and physiology of bone. New York: Academic Press.

Fricke HC and O'Neil JR, 1999. The correlation between ${ }^{18} \mathrm{O} /{ }^{16} \mathrm{O}$ ratios of meteoric water and surface temperature: its use in investigating terrestrial climate change over geologic time. Earth Planetary Science Letters 170: 181-196, DOI 10.1016/S0012-821X(99)001053.

Fuller BT, Fuller JL, Sage NE, Harris DA, O'Connell TC and Hedges REM, 2004. Nitrogen balance and $\delta^{15} \mathrm{~N}$ : why you're not what you eat during pregnancy. Rapid Communications in Mass Spectrometry 18: 2889-2896, DOI: 10.1002/rcm.2090.

Gałasińska I and Gałasiński W, 1959. Związane z wiekiem zmiany w zawartości wody, wapnia i fosforu w kościach ludzkich (Agerelated changes in water, calcium and phosphorous content in human bone). Przeglad antropologiczny 25: 161-170, (in Polish).

Gat JR, 1996. Oxygen and hydrogen isotopes in the hydrologic cycle. Annual Review of Earth and Planetary Sciences 24: 225-262, DOI 10.1146/annurev.earth.24.1.225.

Głąb H, Kępa M, Stepańczak B, Szostek K, Wrębiak A, 2010. Analiza anatomo-antropologiczna oraz demograficzna ludności pochowanej na przedkolacyjnym cmentarzysku w Krakowie (An anatimical, anthropological and demographic analysis of people buried AT the pre-charter burial ground in Kraków). In: Firlet E, ed. Krzysztofory. Zeszyty Naukowe Muzeum Historycznego Miasta Krakowa, Kraków, 28(2):123-136 (in Polish).

Głowa W, 2010. Wczesnośredniowieczne cmentarzysko szkieletowe na Rynku Głównym w Krakowie (Early-Medieval skeletal burial ground in Main Market Square in Kraków). In: Firlet E, ed. Krzysztofory. Zeszyty Naukowe Muzeum Historycznego Miasta Krakowa, Kraków, 28(1): 129-144 (in Polish).

Grimes ST, Collinson ME, Hooker JJ and Mattey D, 2008. Is small beautiful? A review of the advantages and limitations of using small mammal teeth and the direct laser fluorination analysis technique in the isotope reconstruction of past continental climate change. Palaeogeography Palaeoclimatology Palaeoecology 266: 39-50, DOI 10.1016/j.palaeo.2008.03.014.

Grimes V and Pellegrini M, 2013. A comparison of pretreatment methods for the analysis of phosphate oxygen isotope ratios in bioapatite. Rapid Communications in Mass Spectrometry 27(3): 375390, DOI 10.1002/rcm.6463.

Hadjidakis DJ and Androulakis II, 2006. Bone Remodeling. Annals of The New York Academy of Sciences 1092: 385-396, DOI 10.1196/annals.1365.035.

Henton E, Meier-Augenstein W and Kemp H, 2010. The use of oxygen isotopes in sheep molars to investigate past herding practices at the neolithic settlement of Çatalhöyük, central Anatolia. Archaeometry 52: 429-449, DOI 10.1111/j.1475-4754.2009.00492.x.

Hoogewerff J, Papesch W, Kralik M, Berner M, Vroon P, Miesbauer H, Gaber O, Künzel KH and Kleinjans J, 2001. The last domicile of the Iceman from Hauslabjoch: a geochemical approach using $\mathrm{Sr}, \mathrm{C}$ and $\mathrm{O}$ isotopes and trace element signatures. Journal of Archaeological Science 28: 983-989, DOI 10.1006/jasc.2001.0659.

IAEA, 2001. GNIP Maps and Animations. International Atomic Energy Agency, Vienna. Accessible at http://isohis.iaea.org.

Jerszyńska B, 2004. Procesy wzrastania i rozwoju oraz ich uwarunkowania $\mathrm{w}$ średniowiecznych populacjach ludzkich (The processes of growth and development and their determinants in medieval human populations). Poznań: Wydawnictwo Naukowe UAM (in Polish).

Kalkwarf HJ and Specker BL, 2002. Bone mineral changes during pregnancy and lactation. Endocrine 17: 49-53.
Kendall EJ, Montgomery J, Evans JA, Stantis C and Mueller V, 2013. Mobility, mortality, and the middle ages: Identification of migrant individuals in a 14th century black death cemetery population. American Journal of Physical Anthropology 150(2): 210-222, DOI 10.1002/ajpa.22194.

Kenney W and Munce TA, 2003. Invited review: aging and human temperature regulation. Journal of Applied Physiology 95(6): 2598-2603, DOI 10.1152/japplphysiol.00202.2003.

Kępa M, Szostek K, Wrębiak A, Gląb H, Buśko C, Glowa W and Dryja S, 2011. A Case of the Execution of Swedish Soldiers at the Market Square in Cracow (17th c.). International Journal of Osteoarchaeology, DOI 10.1002/oa.1291.

Kirsanow K and Tuross N, 2011. Oxygen and hydrogen isotopes in rodent tissues: Impact of diet, water and ontogeny. Palaeogeography, Palaeoclimatology, Palaeoecology 310: 9-16, DOI 10.1016/j.palaeo.2011.03.022.

Knudson KJ and Price TD, 2007. Utility of multiple chemical techniques in archaeological residential mobility studies: case studies from Tiwanaku-and Chiribaya-affiliated sites in the Andes. American Journal of Physical Anthropology 132: 25-39, DOI 10.1002/ajpa.20480.

Kohn MJ and Cerling TE, 2002. Stable isotope compositions of biological apatite. Reviews in Mineralogy and Geochemistry 48: 455-488, DOI 10.2138/rmg.2002.48.12.

Kohn MJ, 1996. Predicting animal $\delta^{18} \mathrm{O}$ : Accounting for diet and physiological adaptation. Geochimica Cosmochimica Acta 60: 48114829, DOI 10.1016/S0016-7037(96)00240-2.

Lamberts SWJ, van den Beld AW and van der Lely A-J, 1997. The Endocrinology of Aging. Science 278: 419-424, DOI 10.1126/science.278.5337.419.

Leach S, Lewis M, Chenery C, Müldner G and Eckardt H, 2009. Migration and diversity in Roman Britain: A multidisciplinary approach to the identification of immigrants in Roman York, England. American Journal of Physical Anthropology 140: 546-561, DOI 10.1002/ajpa.21104.

Lebon M, Reiche I, Bahain JJ, Chadefaux C, Moigne AM, Fröhlich F, Sémah F, Schwarcz H and Falguères C, 2010. New parameters for the characterization of diagenetic alterations and heat-induced changes of fossil bone mineral using Fourier transform infrared spectrometry. Journal of Archaeological Science 37: 2265-2276, DOI 10.1016/j.jas.2010.03.024.

Levinson AA, Luz B and Kolodny Y, 1987. Variations in oxygen isotopic compositions of human teeth and urinary stones. Applied Geochemistry 2: 367-371, DOI 10.1016/0883-2927(87)90021-7.

Lécuyer C, Fourel F, Martineau F, Amiot R, Bernard A, Daux V, Escarguel G and Morrison J, 2007. High-precision determination of ${ }^{18} \mathrm{O} /{ }^{16} \mathrm{O}$ ratios of silver phosphate by EA-pyrolysis-IRMS continuous flow technique. Journal of Mass Spectrometry 42: 36-41, DOI 10.1002/jms.1130.

Lécuyer C, Grandjean P and Emig C, 1996. Determination of oxygen isotope fractionation between water and phosphate from living lingulids: Potential application to palaeoenvironmental studies. Palaeogeography, Palaeoclimatology, Palaeoecology 126: 101-108, DOI 10.1016/S0031-0182(96)00073-9.

Longinelli A, 1984. Oxygen isotopes in mammal bone phosphate: a new tool for paleohydrological and paleoclimatological research? Geochimica Cosmochimica Acta 48: 385-390, DOI 10.1016/00167037(84)90259-X.

Luz B and Kolodny Y, 1989. Oxygen isotope variation in bone phosphate. Applied Geochemistry 4: 317-323, DOI 10.1016/08832927(89)90035-8.

Łubocka Z and Gronkiewicz S, 2006. Starość na przestrzeni wieków (Aging through the ages). In: Dzieduszycki W and Wrzesiński J, eds. Starość-wiek spełnienia. Funeralia Lednickie, 8: 63-68 (in Polish)

Manolagas SC and Parfitt AM, 2010. What old means to bone. Trends in Endocrinology and Metabolism 21: 369-374, DOI 10.1016/j.tem.2010.01.010.

Manolagas SC, 2000. Birth and death of bone cells: basic regulatory mechanisms and implications for the pathogenesis and treatment 
of osteoporosis. Endocrine Review 21: 115-137, DOI 10.1210/er.21.2.115.

Martin DL and Armelagos GJ, 1985. Skeletal remodeling and mineralization as indicators of health: an example from prehistoric Sudanese Nubia. Journal of Human Evolution 14: 527-537, DOI 10.1016/S0047-2484(85)80031-2.

Mueller-Bieniek A, 2010. Rośliny spożywane w średniowiecznym Krakowie na podstawie danych archeobotanicznych (Plants consumed in Kraków in the Middle Ages according to archaeobotanical data) In: Firlet E, ed. Krzysztofory. Zeszyty Naukowe Muzeum Historycznego Miasta Krakowa, Kraków, 28(2): 151-162 (in Polish).

Mulhern DM and Van Gerven DP, 1997. Patterns of femoral bone remodeling dynamics in a medieval Nubian population. American Journal of Physical Anthropology 104: 133-146, DOI 10.1002/(SICI)1096-8644(199709)104:1<133::AIDAJPA9>3.0.CO;2-S.

Nagy G, Lorand T, Patonai Z, Montsko G, Bajnoczky I, Marcsik A and Mark L, 2008. Analysis of pathological and non-pathological human skeletal remains by FT-IR spectroscopy. Forensic Science International 175: 55-60, DOI 10.1016/j.forsciint.2007.05.008.

Nyman JS, Ni Q, Nicolella DP and Wang X, 2008. Measurements of mobile and bound water by nuclear magnetic resonance correlate with mechanical properties of bone. Bone 42: 193-199, DOI 10.1016/j.bone.2007.09.049.

Oelze VM, Koch J K, Kupke K, Nehlich O, Zäuner S, Wahl J, Weise SM, Rieckhoff S and Richards MP, 2012. Multi-isotopic analysis reveals individual mobility and diet at the early iron age monumental tumulus of magdalenenberg, Germany. American Journal of Physical Anthropology 148: 406-421, DOI 10.1002/ajpa.22063.

Parfitt AM, Travers R, Rauch F and Glorieux FH, 2000. Structural and cellular changes during bone growth in healthy children. Bone 27: 487-494, DOI 10.1016/S8756-3282(00)00353-7.

Pollard AM, Pellegrini M and Lee-Thorp JA, 2011. Technical note: Some observations on the conversion of dental enamel $\delta^{18} \mathrm{O}_{\mathrm{p}}$ values to $\delta^{18} \mathrm{O}_{\mathrm{w}}$ to determine human mobility. American Journal of Physical Anthropology 145(3): 499-504, DOI 10.1002/ajpa.21524.

Prentice A, 2000. Maternal calcium metabolism and bone mineral status. American Journal of Clinical Nutrition 71: 1312-1316.

Prowse TL, Schwarcz HP, Garnsey P, Knyf M, Macchiarelli R and Bondioli L, 2007. Isotopic evidence for age-related immigration to imperial Rome. American Journal of Physical Anthropology 132: 510-519, DOI 10.1002/ajpa.20541.

Radwański K, 1975. Kraków przedkolacyjny (Pre-charter Kraków). Rozwój przestrzenny, Kraków, (in Polish).

Rajman J, 2004. Kraków: Zespół osadniczy, proces lokacji, mieszczanie do roku 1333 (Kraków: settlement, process of location and burghers until 1333 year), Wydawnictwo Naukowe Akademii Pedagogicznej, Kraków, (in Polish).

Reitsema LJ and Crews DE, 2011. Brief communication: Oxygen isotopes as a biomarker for sickle-cell disease? Results from transgenic mice expressing human hemoglobin $\mathrm{S}$ genes. American Journal of Physical Anthropology 145: 495-498, DOI 10.1002/ajpa.21513.

Richards M, Mays S and Fuller B, 2002. Stable carbon and nitrogen isotope values of bone and teeth reflect weaning age at the Medieval Wharram Percy site, Yorkshire, UK. American Journal of Physical Anthropology 119: 205-210, DOI 10.1002/ajpa.10124.

Roberts CA, Millard AR, Nowell GM, Gröcke DR, Macpherson CG, Pearson DG and Evans DH, 2013. Isotopic tracing of the impact of mobility on infectious disease: The origin of people with treponematosis buried in hull, England, in the late medieval period. American Journal of Physical Anthropology 150(2): 273-285, DOI 10.1002/ajpa.22203.

Rogers HJ, Weidmann SM and Parkinson A, 1952. Studies on the skeletal tissues. 2. The collagen content of bones from rabbits, oxen and humans. Biochemical Journal 50: 537-542.

Rosset E, 1959. Proces starzenia sie ludności (The aging of the population) PWG, Warszawa, (in Polish).
Rubenstein D and Hobson KA, 2004. From birds to butterflies: animal movement patterns and stable isotopes. Trends in Ecology and Evolution 19: 256-263, DOI 10.1016/j.tree.2004.03.017.

Ruff CB and Hayes WC, 1988. Sex differences in age-related remodeling of the femur and tibia. Journal of Orthopaedic Research 6: 886-896, DOI 10.1002/jor.1100060613.

Ruimerman R, 2005. Modeling and remodeling in bone tissue. Eindohoven: University Press Facilities.

Sharp Z, 2007. Principles of Stable Isotope Geochemistry. New Jersey: Pearson Prentice Hall.

Shaw B, Buckley H, Summerhayes G, Anson D, Garling S, Valentin F, Mandui H, Stirling C and Reid M, 2010. Migration and mobility at the Late Lapita site of Reber-Rakival (SAC), Watom Island using isotope and trace element analysis: a new insight into Lapita interaction in the Bismarck Archipelago. Journal of Archaeological Science 37: 605-613, DOI 10.1016/j.jas.2009.10.025.

Spence MW, White CD, Longstaffe FJ and Law KR, 2004. Victims Of The Victims: Human trophies worn by sacrificed soldiers from the Feathered Serpent Pyramid, Teotihuacan. Ancient Mesoamerica 15: 1-15, DOI 10.1017/S0956536104151018.

Stawińska N, Ziętek M and Kochanowska I, 2005. Molekularne procesy resorpcji kości i ich potencjał terapeutyczny w leczeniu chorób przyzębia i osteoporozy (Molecular aspects of bone resorption and their therapeutical capability in the periodontal and osteoporotic therapy). Dental and Medical Problems 42: 627-635 (in Polish).

Steiger P, Cummings SR, Black DM, Spencer NE and Genant HK, 1992. Age-related decrements in bone mineral density in women over 65. Journal of Bone and Mineral Research 7: 625-632, DOI 10.1002/jbmr.5650070606.

Stepańczak B, Dzięgielewski K, Łoś J and Szostek K, 2011. Application of FTIR method to identify symbolic graves on the example of the Pomeranian Culture Face Urn from Tuszkowo. Sprawozdania Archeologiczne 63: 135-148.

Stephan E, 2000. Oxygen isotope analysis of animal bone phosphate: Method refinement, influence of consolidants, and reconstruction of palaeotemperatures for Holocene sites. Journal of Archeological Science 27: 523-535, DOI 10.1006/jasc.1999.0480.

Szostek K, 2009.Chemical signals and reconstruction of life strategies from ancient human bones and teeth - problems and perspectives. Anthropological review 72: 3-30, DOI 10.2478/v10044-008-0013-

Szostek K, Haduch E, Stepanczak B, Kruk J, Szczepanek A, Pawlyta J, Głab H, Milisauskas S, 2013. Isotopic composition and identification of the origins of individuals buried in a Neolithic collective grave at Bronocice (southern Poland). Homo, In press, DOI 10.1016/j.jchb.2013.11.001.

Szostek K, Stepańczak B, Szczepanek A, Kępa M, Głąb H, Jarosz P, Włodarczak P, Tunia K, Pawlyta J, Paluszkiewicz Cz and Tylko $\mathrm{G}$, 2011. Diagenetic signals from ancient human remainsbioarchaeological applications. Mineralogia 42(2): 93-112, DOI 10.2478/v10002-011-0009-4.

Turner BL, Edwards JL, Quinn EA, Kingston JD and Van Gerven DP, 2007. Age-related variation in isotopic indicators of diet at medieval Kulubnarti, Sudanese Nubia. International Journal of Osteoarchaeology 17: 1-25, DOI 10.1002/oa.862.

Wang X, Shen X, Li X and Mauli Agrawal C, 2002. Age-related changes in the collagen network and toughness of bone. Bone 31: 1-7, DOI 10.1016/S8756-3282(01)00697-4.

Warinner C and Tuross N, 2010. Brief communication: Tissue isotopic enrichment associated with growth depression in a pig: Implications for archaeology and ecology. American Journal of Physical Anthropology 141: 486-493, DOI 10.1002/ajpa.21222.

West JB, Bowen GJ, Cerling TE and Ehleringer JR, 2006. Stable isotopes as one of nature's ecological recorders. Trends in Ecology and Evolution 21: 408-414, DOI 10.1016/j.tree.2006.04.002.

White CD, Spence MW, Longstaffe FJ and Law KR, 2004a. Demography and ethnic continuity in the Tlailotlacan enclave of Teotihuacan: the evidence from stable oxygen isotopes. Journal of Anthropological Archaeology 23: 385-403, DOI 10.1016/j.jaa.2004.08.002. 
White CD, Spence MW, Stuart-Williams Q and Schwacz HP, 1998. Oxygen isotopes and the identification of geographical origins: the Valley of Oaxaca versus the Valley of Mexico. Journal of Archaeological Science 25: 643-655, DOI 10.1006/jasc.1997.0259.

White Ch, Longstaffe FJ and Law KR, 2004b. Exploring the effects of environment, physiology and diet on oxygen isotope ratios in ancient Nubian bones and teeth. Journal of Archaeological Science 31: 233-250, DOI 10.1016/j.jas.2003.08.007.

White TD and Folkens PA, 2005. The human bone. Manual. Academic Press, Elsevier Inc.

Widory D, 2004. Oxygen and nitrogen isotopic fractionations during human respiration. Comptes Rendus Biologies 327: 729-734, DOI 10.1016/j.crvi.2004.07.001.

Williams JS, White CD and Longstaffe FJ, 2005. Trophic level and macronutrient shift effects associated with the weaning process in the postclassic Maya. American Journal of Physical Anthropology 128: 781-790, DOI 10.1002/ajpa.20229.

Włodarczak P, Szczepanek A, Stepańczak B, Jarosz P and Szostek K, 2011. Analiza proporcji stabilnych izotopów tlenu $\left({ }^{18} \mathrm{O} /{ }^{16} \mathrm{O}\right) \mathrm{w}$ kościach przedstawicieli ludności kultury ceramiki sznurowej z Malżyc - badania pilotażowe (Analysis of the ratio of stable oxygen isotopes $\left({ }^{18} \mathrm{O} /{ }^{16} \mathrm{O}\right)$ in human bones from the Corded Ware Culture from Malżyce - pilot study). Archeologia Polski 56: 45-61 (in Polish).

Wojtal P, Makowiecki D, Wertz K, Wilczyński J, Miękina B and Zabilska M, 2010. Wstepne wyniki badań zooarcheologicznych szczątków kostnych z wykopalisk prowadzonych na Rynku krakowskim w latach 2005-2007 (Preliminary results of the zooarchaeological tests of skeletal remains unearthed during the excavation in Main Market Square in Kraków in the years 2005-2007). In: Firlet E, ed. Krzysztofory. Zeszyty Naukowe Muzeum Historycznego Miasta Krakowa, Kraków, 28(2): 137-150 (in Polish).

Wolf N, Bowen GJ and del Rio CM, 2011. The influence of drinking water on the $\delta \mathrm{D}$ and $\delta^{18} \mathrm{O}$ values of house sparrow plasma, blood and feathers. Journal of Experimental Biology 214: 98-103, DOI 10.1242/jeb.050211.

Wong WW, Cochran WJ, Klish WJ, Smith EO, Lee LS and Klein PD, 1988. In vivo isotope-fractionation factors and the measurement of deuterium-and oxygen-18-dilution spaces from plasma, urine, saliva, respiratory water vapor, and carbon dioxide. American Journal of Clinical Nutrition 47: 1-6.

Wright LE and Schwarcz HP, 1996. Infrared and isotopic evidence for diagenesis of bone apatite at Dos Pilas, Guatemala: Palaeodietary implications. Journal of Archaeological Science 23: 933-944, DOI 10.1006/jasc. 1996.0087

Yoder C and Bartelink E, 2010. Effects of different sample preparation methods on stable carbon and oxygen isotope values of bone apatite: a comparison of two treatment protocols. Archaeometry 52: 115-130, DOI 10.1111/j.1475-4754.2009.00473.x.

Zanconato S, Cooper DM, Armon Y and Epstein S, 1992. Effect of increased metabolic rate on oxygen isotopic fractionation. Respiration Physiology 89: 319-327, DOI 10.1016/0034-5687(92)90090J.

Zoll-Adamikowa H, 1971. Wczesnośredniowieczne cmentarzyska szkieletowe Małopolski, część 2 (Early-medieval burial groung in Malopolska, part 2), Analiza, Wrocław (in Polish).

Żołądź JA, Majerczak J and Duda K, 2011. Starzenie się a wydolność fizyczna człowieka (Ageing and human physical exercise capa city). In: Górski J, ed. Fizjologia wysiłku i treningu fizycznego. Warszawa: Wydawnictwo Lekarskie PZWL (in Polish). 